INMR

19,4

\section{2}

Received 14 October 2020

Revised 8 April 2021

7 July 2021

Accepted 30 July 2021

\title{
Integrated co-creation process with multiple stakeholders in innovation networks
}

\author{
Sergio Takahashi \\ Faculty of Economics, Admnistration and Accounting of Ribeirão Preto, \\ University of São Paulo, São Paulo, Brazil, and \\ Vania Passarini Takahashi \\ Faculty of Pharmaceutical Sciences of Ribeirão Preto, University of São Paulo, \\ São Paulo, Brazil
}

\begin{abstract}
Purpose - The purpose of this paper is to study the organizational processes in co-creation with multiple stakeholders within the scope of innovation networks. It consists of analyzing the necessary adaptation of organizational processes and to structure a proposal of an integrated process.

Design/methodology/approach - This paper is a review article, an analysis of relevant articles in the areas of co-creation with multiple stakeholders, innovation networks, dynamic capabilities and organizational aspects linked to network organization which reflect on the main differences by relating them to the relevant literature.

Findings - Identification of related processes: Innovation development, knowledge integration/sharing, Coevolution, Value Co-creation, Value Capture, Stakeholders capabilities, and elements of an integrated process in an innovation network.

Originality/value - Proposition of an integrated co-creation process with multiple stakeholders in an innovation network based on dynamic capabilities with the elements of literature and an analysis of the model variables. This process makes it possible, before reconfiguring the network itself, to create and to define the Project in an integrated manner. They also promote an evolution in the commitment, in the relationship and in the sharing of knowledge among the stakeholders and in the anticipation and evaluation by the stakeholders. Keywords Co-creation, Multiple stakeholders, Innovation network, Dynamic capabilities, Participation design

Paper type Conceptual paper
\end{abstract}

\section{Introduction}

Traditional "enterprise-centric" innovation has evolved into "interaction" based innovation in a co-creation process, where consumers are engaged in the process of defining and creating value (Prahalad \& Ramaswamy, 2004; Galvano \& Dalli, 2014). Thus, the "co-creation" label has proliferated in the last decade, however with little consensus on what "co-creation" is (Ind \& Coates, 2013; Ramaswamy \& Ozcan, 2018).

Ribeiro, Tavares, and Costa (2016) found in a review study from the databases of the Web of Science and Scopus, using the bibliometric analysis technique, that between the years 2000 and 2014, there was a peak of publications related to the theme of co-creation of value, and

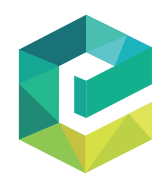

Innovation \& Management Review Vol. 19 No. 4,2022 pp. 382-399 Emerald Publishing Limited $2515-8961$

DOI 10.1108/INMR-10-2020-0142 (c) Sergio Takahashi and Vania Passarini Takahashi. Published in Innovation \& Management Review. Published by Emerald Publishing Limited. This article is published under the Creative Commons Attribution (CC BY 4.0) licence. Anyone may reproduce, distribute, translate and create derivative works of this article (for both commercial and non-commercial purposes), subject to full attribution to the original publication and authors. The full terms of this licence maybe seen at http://creativecommons. org/licences/by/4.0/legalcode. 
identified that co-creation presents itself as a horizontal, interdisciplinary and multidisciplinary subject.

Studies show that there are three main theoretical perspectives for studying co-creation: service sciences (Vargo \& Lusch, 2008) marketing and consumer research (Ranjan \& Read, 2016) and technology innovation and management (Galvano \& Dalli, 2014; Najera-Sanchez, Ortiz de Urbina, \& Mora-Valentin, 2020). The interest of our research is focused on the perspective of co-creation in technology innovation and management.

In a bibliographic coupling analysis on co-creation, Najera-Sanchez et al. (2020) found that interest in co-creation in innovation and technology has been growing. According to the authors, co-creation extended to other stakeholders, and there are several roles that the client can assume, such as being a source of information, co-developer and innovator. They also obtained three research streams: open innovation, consumer-centric analysis, and service ecosystem and innovation.

There is a research vacuum (void) between open science, Innovation and co-creation (Ramirez \& Penalvo, 2018; Najera-Sanchez et al., 2020). Huizingh (2011) argues that the context of open innovation is poorly understood, requiring research on the organizational characteristics of co-creation of the internal and external environment (Prahalad \& Ramaswamy, 2004b).

Considering this, it appears that a network of companies in multiple collaboration is essential to create the right environment for the development of co-creation, and in these networks several stakeholders must work together to co-create innovative value (Reypens, Lievens, \& Blazevic, 2016; Ramirez \& Penalvo, 2018).

The shift toward collaborating with several stakeholders simultaneously during the innovation process (Kazadi, Lievens, \& Mahr, 2016) is driven by two important trends. First, companies increasingly demand complex knowledge during their innovation process, and this complex knowledge requires the input of several parties (Hsiao, Tsai, \& Lee, 2012; Kazadi et al., 2016). Second, stakeholders are becoming increasingly empowered, interconnected and willing to share their knowledge and ideas with companies (Gebauer, Füller, \& Pezzei, 2013).

Recent considerations have shifted to a more holistic assessment of the role played by all actors involved (from suppliers to employees and society in general) in creating value (Pera, Occhiocupo, \& Clarke, 2016).

Therefore, value co-creation can be characterized as a cooperative process (Prahalad \& Ramaswamy, 2004b; Romero \& Molina, 2011), and refers to any act of collective creativity (Sanders \& Stappers, 2008). Following this approach, organizations are trying to re-invent their strategies by participating in collaborative networks in order to maintain their competitive advantages through the emergence of new value creation practices (Romero \& Molina, 2011).

In innovation networks, the structure becomes more horizontal, with processes prevailing in order to promote the work to be carried out (De Kay, 2011). The approaches about it are fragmented in the literature, making it impossible to use the processes in an integrated manner. As co-creation is a multidisciplinary theme, there is an opportunity for approaches that promote complementarity among knowledge.

The research's question is "How to provide an integrated process for co-creation with multiple stakeholders in innovation networks, contemplating the complementarity of the various approaches?".

Our aim with this theoretical essay is to structure a proposal of an integrated process for co-creation with multiple stakeholders in innovation networks in which dynamic capabilities emerges as an integrating link. The method used for this conceptual article is the narrative literature review (Paré, Trudel, Jaana, \& Kitsiou, 2015). The search's strategy is selective and iterative with nature of primary sources conceptual and empirical of relevant articles in the areas of co-creation with multiple stakeholders, innovation networks, knowledge sharing/ integration, dynamic capabilities and organizational aspects linked to network organization. 
INMR 19,4

\section{4}

The methods for analyzing findings are the narrative synthesis that at first, seeks to identify and show the complementarity between the dimensions studied. At the second moment, the structuring of the development stages considering the behavior of variables in the respective phases with the adoption of the sensing, seizing and transformation process as an integrating dimension.

The paper is organized as follows, besides the introduction. First, we describe the main characteristics of innovation networks and structural aspects. Second, we present insights of interconnected processes in innovation networks. Third, the main studies of co-creation with multiple stakeholders are presented. Fourth, we present the beginning of the study of dynamic capabilities. Then, there is the proposition about relationships between co-creation, networks and multiple stakeholders, and dynamic capabilities. Finally, we draw some final conclusions, stressing the potentiality, some limitations and directions for future research.

\section{Innovation network}

There is an evolution toward co-creation as an activity that occurs between economic and social actors within and throughout networks, interacting and exchanging (Michel, Vargo, \& Lusch, 2008; Pera et al., 2016), therefore the locus of innovation is passed from the individual and company to the network in which the company is inserted (Pittaway, Robertson, Munir, Denyer, \& Neely, 2004; Reypens et al., 2016; Kazadi et al., 2016).

Organizationally, there is a shift from the rigidity and formality of the hierarchy to the empowerment and autonomy of horizontal work, providing a network-based organization (Kodama, 2007; Scharmer, 2010; De Kay, 2011).

Innovation networks can be defined as the union of two or more parties, institutions or individuals, with the purpose of creating distinct knowledge during the innovation process (Kodama, 2007; De Kay, 2011; Arranz \& de Arroyabe, 2012; Kazadi et al., 2016).

It is a way of accessing technological resources or improving an organization's competitive positioning without the need to acquire or possess them through more traditional paths (Miotti \& Sachwald, 2003). This strategic advantage stems from the specific assets companies dedicate to complementarities between their own resources and those of their partners.

There are various sets of actors: companies, universities, private research centers, investors, government agencies, suppliers, clients, etc. (Corsaro, Cantú, \& Tunisini, 2012). This characterizes an organizational extension and enables the exploration of new opportunities and the development of the principal competences of the company (Corsaro, Cantú, \& Tunisi, 2012).

Broadly speaking, studies have suggested that benefits from networks include the advantage of collaboration among all involved to create distinct knowledge during the innovation process, cost reduction, risk sharing, access to financial capital, complementary assets that can be exploited together and increased ability for rapid learning and transferability of knowledge (Kodama, 2007; Arranz \& de Arroyabe, 2012; Kazadi et al., 2016).

This combination of dispersed resources, knowledge and capabilities (Perks \& Moxey, 2011) is becoming increasingly important due to the increased complexity of new products and services (Pullen, De Weerd-Nederhof, Groen, \& Fisscher, 2012).

Innovation network studies also provide elements of how to integrate multiple existing stakeholders during the innovation process (Kazadi et al., 2016). Through networks, technological processes are developed by a wide range of agents, and the multiple interactions between them describe an interactive, non-sequential and nonlinear process (Roy, Sivakumar, \& Wilkinson, 2004; Kodama, 2007).

\subsection{Network structure studies}

One of the main elements of the network structural design is to define and search for a suitable partner (Miotti \& Sachwald, 2003), thus, partners and resources shape the network structure (Arranz \& de Arroyabe, 2012). 
In order to enhance interorganizational collaboration to enable the sharing of knowledge and interactive learning processes between companies, a network structure must focus on the diversity of its direct contacts, which is based on weak or strong interpersonal and interorganizational relationships (Capaldo, 2007).

In light of this, strong bonds are those long-lasting, repeated and socially dense relationships, and there cannot be non-redundant contacts in the total amount of contacts in the network; these are known as bridges. However, bridges can be the weak links that can connect a company to areas of knowledge that previously were difficult to access through strong ties, therefore non-redundant contacts can be added (Rowley, Behrens, \& Krackhardt, 2000). Thereby, there is a complementarity between weak and strong ties, leading to an idea of their integration within the network due to the coexisting opportunities for exploration and exploitation, and could therefore represent a distinct relational capacity for the main actor in the network to form a dual network (Capaldo, 2007; De Kay, 2011).

The rapid formation of collaborative networks requires an interoperable infrastructure with operational rules and common cooperation agreements, among other aspects, and with a basic level of trust between organizations (Camarinha-Matos and Afsarmanesh, 2005, 2007), Romero and Molina (2011). One solution is to create an association of entities that are prepared to cooperate whenever an opportunity arises. It is a "breeding environment" as described by Camarinha-Matos and Afsarmanesh (2007, p. 125), who define it as "an association of organizations and their related supporting institutions, adhering to a base long-term cooperation agreement, and adoption of common operating principles and infrastructures, with the main goal of increasing both their chances and their preparedness towards collaboration in potential Virtual Organizations”. This is regulated, open, nonetheless with a controlled border by its members.

In this regard, Kristensen and Lotz (2011) describe the deliberation community that provides better possibilities for negotiating solutions of conflict, helping teams to reflect on their work toward an evolution, resulting from many discussions between the teams, new information, and new reflection points.

Moreover, Reypens, Lievens, and Blazevic (2020) in studies of orchestration in multistakeholder networks, found that orchestrators that rely on hybrid orchestration, alternating between the modes of dominant and consensual orchestration, deal with the complexities of simultaneously and temporarily with a large number and diversity of stakeholders in response to the network's emerging challenges.

These aspects of structure and committees are related to project governance (Hakanen \& Jaakkola, 2012; Müller et al., 2016; Samset \& Volden, 2016), which also refers to the processes, systems and regulations that the financing party must have to ensure that projects are successful: how to design, define and sell integrated solutions, ensure adequate quality at entry, compliance with agreed objectives and standards for quality review of key assessment documents.

\section{Interconnected processes in innovation network}

The existence of complementary competences implies in a network, at the same time, the existence of differences in products, markets and organizational structures and goals. These differences can cause serious barriers for the coordination to link business processes and achieve joint and individual goals (Prahalad \& Ramaswamy, 2004; Takahashi \& Takahashi, 2007).

However, these antagonisms of complementary competences can be minimized by the interconnected processes of developing innovation in networks, namely innovation development, knowledge integration, co-evolution of business and social relations (Swan \& Scarbrough, 2005).

\section{Integrated co-creation process}

385 
INMR

19,4

\subsection{Innovation development}

Technological innovation development is characterized by continuous learning (Verona \& Ravasi, 2003; Takahashi \& Takahashi, 2007) in which companies develop new products and new processes. It depends on access to knowledge and influences the speed of innovation and dynamics of the network. The evolution of an innovative network itself occurs in connection with technological cycles and the system related to the agents. Therefore, it addresses the participatory design and user-centered approach (Brown, 2009; Kelly \& Matthews, 2014; Luchs, Swan, \& Griffin, 2015), in an invigorated way (Rill, 2016).

Design is recognized by practitioners and academics as a source of innovation (Landoni et al., 2016) and also as an important strategic asset, being seen as a strategic tool given the sustainable competitive advantage it can give the company (Landoni et al., 2016; Takahashi \& Takahashi, 2019). co-creation is like the part of the best practices in design thinking (Rill, 2016), and unlike other participation practices, there is direct group engagement, with key stakeholders working together in the same space (Sanders \& Stappers, 2008).

Participatory design is an evolution from the approach of user-centered design (Brown, 2009; Postma, Zwartkruis-Pelgrim, Daemen, \& Jia, 2012; Weigel, 2015; Landoni et al., 2016) as it has the user as its partner.

Thus, there is an increase in user participation functions (Lee, Olson, \& Trimi, 2012), especially in the early stages of design (Sanders \& Stappers, 2008; Dell'Era \& Landoni, 2014). It works with interventionist methods of engagement and active involvement with users in developmental practices, providing an exclusive acquisition of the real-time process of user centered innovation, although it also lacks a clear connection to market conditions. Buur and Matthews (2008, p. 259) add that "the deployment of participatory design is itself, often an exercise in organizational change, bringing diverse stakeholders together who confront each other with very different perspectives on the issues. Participatory design also brings strong design competence to bear on use and user issues, something that forms a valuable complement to design anthropology".

In a specific instance of co-creation linked to participatory design, we have co-design. Co-design can be characterized as a creative activity by designers and untrained designers working together in the design development process, a collective activity applied throughout the design process (Sanders \& Stappers, 2008). Sanders and Stappers (2008, p. 12) describe changing roles in co-design as "in co-design, on the other hand, the roles get mixed up: the person who will eventually be served through the design process is given the position of 'expert of his/her experience', and plays a large role in knowledge development, idea generation and concept development. In generating insights, the researcher supports the 'expert of his/her experience' by providing tools for ideation and expression. The designer and the researcher collaborate on the tools for ideation because design skills are very important in the development of the tools. They may, in fact, be the same person. The designer still plays a critical role in giving form to the ideas".

The thinking behind participatory (or cooperative) design is to provide some empowerment to workers and generate their active contribution, being a powerful democratizing element in co-creation that can also be used to involve citizens and influential groups in co-creating social innovation in various areas (Ind \& Coates, 2013).

\subsection{Knowledge integration/sharing}

In regard to the integration of knowledge, innovation stems from the application of new elements of knowledge or a new combination of existing elements (Nonaka \& Takeuchi, 1995; Okhuysen \& Eisenhardt, 2002), where knowledge is transferred, but also created (Orlikowski, 2002). Following this logic, innovation networks develop, acquire and integrate the knowledge and competences needed to create and bring complex solutions to the market 
(Hedlund, 1994; Corsaro, Cantú, \& Tunisini, 2012). The generation and transmission of new forms of tacit knowledge is eased and may even be conditioned by a certain level of social capital, which is the set of resources, tangible or virtual, that accumulate for an actor through that actor's social relations, facilitating the achievement of goals (Hedlund, 1994; Batjargal, 2003; Takeuchi \& Nonaka, 2008). Examples of knowledge conversion process: socialization, externalization, combination and internalization (Nonaka \& Takeuchi, 1995). These processes can be extended for the interorganizational knowledge interchange processes (Hedlund, 1994; Kodama, 2007).

Complementing, meetings of co-creation are common, where there is openness, sharing thoughts for interpretations, a wealth of divergent perceptions, coexistence with disagreements, a deep sense of connection, commitment and participation in teams (Ramaswamy, 2009; Vargo \& Lusch, 2016).

The main difference between knowledge transfer and sharing is that transfer refers to the acquisition of knowledge, and sharing involves the socialization process (Nonaka \& Takeuchi, 1995) with consensus and mutual identification. Sharing has a deeper understanding and agreement about knowledge (Argote \& Miron-Spektor, 2011). Thus, Von Krogh, Ichijo, and Nonaka (2000) characterize what socialization means when members of a community not only understand each other in shared situations, they also agree on a common definition and justified truth about how to act in this situation; when membership increases in a community and there is mutual identification between these members and each contributes to the welfare of the other members. In new product development process, tacit knowledge is shared through the deep socialization of a project team (Von Krogh et al., 2000), as it secures success in the face of uncertainty because it facilitates a shared interpretation of unexpected alterations, emerging problems and potential solutions (Stock, An Tsai, Jiang, \& Klein, 2021).

In these circumstances, Burbiel (2009, p. 47) says that "Knowledge sharing, in turn, is encouraged if teams are perceived as cooperative (rather than competitive) and if employees expect to be treated in a fair way".

Additionally, the integrative thinking (Martin, 2007) also enables the integration of opposites, or the complementarity of antagonistic solutions. Martin (2007) characterizes the integrative thinking approach that works with the principles of "Design Thinking" applied to business strategy. It is based on the evolution of an opposable mind that enables the integration of opposites, or the complementarity of antagonistic solutions, following the principle of the synthesis of dialectical thought. Opponent movements are part of the evolution of humanity. The "opposing mind", on the other hand, makes it possible to keep conflicting ideas in constructive tension, seeking a way to integrate the advantages of a solution without neutralizing the opposite solution, working beyond alternatives rather than between them (Collins \& Porras, 1997).

\subsection{Co-evolution of social and business relationships}

Innovative activities explore a wide variety of relationships that involve multiple dimensions of the network (Ceci \& Iubatti, 2012); networks of people, groups, and organizations are important platforms that facilitate activities at the base of knowledge (Owen-Smith \& Powell, 2004; Vicenzo \& Mascia, 2012). And any company is embedded in a network of social relationships that influence the behaviour of actors and represents the basis for cooperative and innovative behaviour.

Furthermore, innovation also develops through the co-evolution of social and business relationships. Co-evolutionary's logic is associated with different ways in which customer and stakeholder value emerges and is then interrupted by the creation of new connections and knowledge within ecosystems that generate new types of value for the customers and
Integrated

co-creation

process

387 
INMR 19,4

stakeholders (Aarikka_Stenroos \& Ritala,2017). It examines the characteristics of dynamism and evolution in the system, as well as the inherent interdependence of the actors involved, with the multiple dynamics that interact with each other over time. Co-evolution occurs between markets and science, technology and market structures, culture, and regulatory structures, as it implies a prolonged period of coexistence, experimentation and competition for resources (Aarikka_Stenroos \& Ritala, 2017).

\section{8}

\section{Co-creation with multiple stakeholders}

From co-creation with multiple stakeholders new challenges arise due to the diversity of characteristics, interests and objectives (Kazadi et al., 2016), and cooperation (Hakanen \& Jaakkola, 2012).

Reypens et al. (2016) mentions that at least three aspects require consideration. First, traditional results at the company level, such as patents or market share, no longer fully represent the range of value created for the various stakeholders in a network, as the cocreation of value in a network is more ambiguous and perceptions of value are likely to differ between partners. Second, the co-creation of value is spread among various stakeholders at the network level. Third, one must seek to understand not only how value is created, but also how stakeholders capture their share of value.

In this regard, the actors in a business network must have a shared vision of the type of solution needed, the operations and processes necessary for the creation of this solution, as well as the intended result (Hakanen \& Jaakkola, 2012). Thus, it is necessary to adjust the content of the solutions and the co-creation process according to the clients' heterogeneous value expectations, as well as taking into account the objectives, preferences and resources of the supply companies (Hakanen \& Jaakkola, 2012).

Moreover, the more knowledge-intensive and customized a solution is, the greater the criticality for the effectiveness of the solutions, since the challenges of mutual understanding about the customer's needs increase (Hakanen \& Jaakkola, 2012).

Many of the processes presented in item 2 of this article greatly assist these aspects described above. The work by Reypens et al. (2016) adds to this, as it contributes toward the characterization of two processes related to value: co-creation and capture.

In value co-creation processes, value is co-created when stakeholders interact and contribute resources to jointly resolve agreed issues. Reypens et al. (2016) outlined three distinct process. Coordination deals with the planning and monitoring of various activities and stakeholders. It also includes sharing information to encourage synergies and avoid overlapping activity, while also managing needs, expectations and understanding their contexts. Consultation between interested parties includes sharing and discussing thoughts, ideas, needs and expectations. It is inclusive and participatory, hence it encourages an open dialogue. To achieve a commitment, all parties should listen and reconcile their views before making decisions. This gradual approach balances a variety of interests, motives and expectations.

Value capture processes, on the other hand, allow interested parties to benefit from the results at the network level. Three distinct processes at the stakeholder level are identified in capturing value (Reypens et al., 2016). Anticipating the types of value to be created, before and during the collaboration. Assessment of the value of the results that the partners intend to obtain from the collaboration. Without a common outcome to maintain motivation in all stakeholders, value creation would be hampered if individual stakeholders do not see the added value for their organizations. These assessments need constant evaluation as the collaboration progresses. Application is the transfer of the value created for each organization. Organizations benefit from the result of shared resources, which could be used to replace or complement internal investments. 
In order to anticipate and manage co-creation, Kazadi et al. (2016) presents two specific capacities related to the differential performance of the co-creation activities of the interested parties and which are related to the potential and absorption capacity realized in the project.

Regarding the co-creation of "pre-project" stakeholders, there are two capacities. First, the stakeholder network capacity that reflects a company's ability to find and attract appropriate stakeholders for co-creation activities, and to promote a combination of initiation, development and termination of relationships. Second, stakeholder skills mapping. This ability provides an explicit overview of the different competencies present in each of its different stakeholders.

Co-creation of stakeholders in the project strengthens a company's ability to generate valuable knowledge from this type of collaboration and there are two capabilities: First, the "Relational capacity of stakeholders" that implies a company's ability to manage its relationships with a multitude of stakeholders in an ongoing co-creation project, as well as the relationships of these stakeholders with each other. Second, stakeholder knowledge management refers to the company's ability to capture and explain all relevant knowledge generated during stakeholder co-creation activities. This involves not only the knowledge generated in the interaction between the focal company and specific stakeholders, but also the knowledge generated by the interaction between stakeholders, as already seen in item 2 .

Another process structure is presented by Ketonen-Oksi and Valkokar (2019), with the aim of emphasizing the active, creative and social nature of the value co-creation process, supporting the ways in which the value co-creating actors are involved in the process of continuous interaction through the creation and exchange of knowledge. The process of cocreating value begins when the actors of the ecosystem come together in terms of mutually shared interests in innovation and has four phases: (1) Co-experience: the actors in the ecosystem become aware of their needs and expectations and gradually start to mirror them in relation to the needs and expectations of other actors in the ecosystem that represent several different individuals and organizations. (2) Co-definition: the actors use each other's abilities to share their internal models and perceptions of value co-creation. (3) Co-evolution: the focus finally turns to real value propositions, strengthened by active communication between actors in the ecosystem. (4) Co-development: where the co-creation of concrete value - or co-destruction - is updated and evaluated.

\section{Dynamic capabilities}

\subsection{Definition and characteristics}

In the respect that companies need the appropriate capabilities to manage the socially complex process of involving several stakeholders simultaneously during a process, dynamic capabilities continue as co-creation capacities of stakeholders (Teece, Pisano, \& Shuen, 1997; Kazadi et al., 2016).

Teece et al. (1997, p. 516) initially defined dynamic capabilities: “...as the company's ability to integrate, build and reconfigure internal and external competencies to deal with rapidly changing environments".

These are related to the manipulation of the configuration of resources and capacities, including value creating processes (Eisenhardt \& Martin, 2000), while considering the resources of physical and human capital, the structure, systems, and culture, recognizing them as an "Organizational Combination" (Verona \& Ravasi, 2003).

The dynamic capabilities are directed toward strategic change and aligning the organization with the environment, and act on operational capabilities (Zahra, Sapienza, \& Davidsson, 2006) or ordinary capabilities (Teece, 2016) by changing and reconfiguring them. In this regard, it follows the concept of "evolutionary aptitude" which depends on how well an organization's dynamic capabilities correspond to the context in which the organization
Integrated co-creation process

389 
INMR 19,4

operates. In other words, the company's survival indicates whether an organization is able to adapt to its external environment, the company's growth incorporates the extent to which the organization has grown in size over time (Helfat et al., 2007; Teece, 2016).

They have greater "equifinality" which means the existence of multiple paths for the development of the same dynamic capacity, characterized by the impossibility of imitating this, because each company can develop in different ways (Eisenhardt \& Martin, 2000; Sunder, Ganesh, \& Marathe, 2019).

\subsection{The behavioral processes in dynamic capabilities}

Sunder et al. (2019) present a specific dynamic capability type, a behavioral processes and it consist in three phases: sensing, seizing and transforming.

It is possible to verify that this initial concept has been expanded by Teece (2009), who describes that in the tradition of dynamic capabilities, the essence of strategy involves the selection and development of technologies and business models that create competitive advantage by assembling and orchestrating resources that are difficult to replicate, thus shaping the competition itself.

5.2.1 Sensing (and shaping) opportunities and threats. This is an activity of recognition and creation of opportunities, with activities of searching, creation, learning, interpretation and exploration, which consist of feeling, forming and calibrating opportunities. It is composed of external processes for changing customer needs, customer innovation, target market segments, research, analysis of the structural evolution of the industry, markets, suppliers and competitors, and the understanding of latent demands. There must be processes to drive internal research and development (R\&D), likewise external development processes. Added to these are the research and analysis of technological innovation cycles, future scenarios of impact and behavior of these technologies, and the dynamics of changes according to opportunities.

Teece (2009) emphasizes that companies should research the core, as well as the periphery of their business ecosystem, as the research must include potential employees, customers, and suppliers. Customers are sometimes the firsts to realize the potential for applying new technologies. In a recent research, Teece (2016) argues that the sensing phase requires an entrepreneurial management action, denominated co-development.

5.2.2 Seizing opportunities. This is a business model design and strategic investment activity. It consists in the activities of analyzing and deciding when, where and how much to invest, the development of the network of related companies, and the design of the business model and the organizational design.

In business model design, the company must create, adjust and, if necessary, replace its business model. A business model conceptualized by Teece (2009), consists of a plan for the organizational and financial "architecture" of a company. This model makes assumptions about the behavior of revenues and costs, and probably the behavior of the customer and competitors. Further, it outlines the solution needed to make a profit. Once adopted, it defines how the company "goes to the market".

According to Teece (2016, p. 213) "The activities involved in seizing an opportunity require both entrepreneurship and leadership on the part of managers. Devising a business model that will allow the firm to capture a share of the value it creates for customers is a core entrepreneurial skill. Convincing the organization and its partner firms of the rightness of this new path necessitates leadership".

5.2.3 Transforming. It consists on promoting the necessary transformation to implement the designed business and organizational model (Teece, 2018). Transforming is about the ability to recombine and reconfigure assets and organizational structures as the company grows and, as markets and technologies change.

Transformation is necessary to maintain the evolutionary aptitude and, if necessary, to try to escape from unfavorable path dependencies. 
To sustain dynamic capabilities, decentralization, orchestration of semi-continuous assets and corporate renewal, including redesigning routines, are required.

This phase includes building, maintaining and adjusting the complementarity of offers, systems, routines and product structures. Within the company, the old and the new must complement each other, if they do not, the business units must be discarded or placed in some type of separate structure. Successfully managing transformations requires good leadership skills because tensions inevitably arise during the process of change (Teece, 2016).
Integrated co-creation process

\section{Integrated co-creation processes with multiple stakeholders based on dynamic capabilities}

In the literature review, important processes and structural elements of an innovation network were presented in the context of co-creation with multiple stakeholders in an innovation network. However, they are dispersed in the literature, making the use of an integrated perspective impossible.

Preikschas, Cabanelas, Rüdiger, and Lampón (2017) cite that co-creation provides an approach to combining external knowledge and internal capabilities, thus the combination of value co-creation and dynamic capabilities can offer new insights into the studies of microprocesses in co-creation. In another study, Vrontis, Basile, Andreano, Mazzitelli, and Papasolomou (2020), when studying small and medium-sized enterprises (SMEs), found that innovative companies are characterized by dynamic capabilities and network strategies.

Sunder et al. (2019) conducted systematic review of dynamic capabilities publications between 1990 and 2016, and identified 133 relevant articles. The authors developed a morphological analysis containing 26 variant types of dynamic capabilities and suggested for future works the investigations of links or interrelationships between of dynamic capabilities.

Some dynamic capabilities cited by authors were also described in the previous sections in this work (in parentheses and bold), such as: networks and relationships (the innovation network, knowledge sharing and business relationships consultation); change process (the innovation development); information, knowledge and organizational systems (the knowledge integration); value creation (value co-creation); managerial actions (coordination aspects of the value co-creation).

In a sense of application of co-creation with multiple stakeholders, before reconfiguring the network itself, there are processes required to create and to define the project. These processes in the context of multiple stakeholders also should promote an evolution in the commitment, in the relationship, in the knowledge sharing among the stakeholders, in the anticipation and evaluation by stakeholders.

Hence, the sensing, seizing and transforming are presented as an integrating element of these processes, enabling a theoretical and practical synthesis.

Therefore, the following proposition is formulated:

The Integrated co-creation Process with Multiple Stakeholders based on Dynamic Capabilities is the company's ability to integrate, build and reconfigure internal and external competencies to deal with rapidly changing environments in a cooperative context. This process has three phases: co-creation Sensing, co-creation Seizing, and co-creation Transformation.

Co-creation sensing phase: this is an activity of recognition and creation of opportunities, with activities of research, creation, learning, interpretation, and exploration, in a cooperative way with multiple stakeholders.

The phase begins with pre-sensing, an initial activity that precedes the Innovation process itself and which aims to anticipate and prepare for the beginning of the process.

It contemplates previous studies and research, elaboration of previous future scenarios, emerging demands, and the general analysis of stakeholders, regarding their purposes and 
INMR 19,4

392 values, interests and competences. Here, there is the composition of activities of initial contacts with stakeholders in order to attract them, starting the relationship itself (networking, mapping).

This can be formed by several companies that are already partners, or by a main company that will orchestrate innovation and the execution can happen through initial meetings and workshops so that adjustments can be made to the process, methods and initial schedule. It is related to the "breeding environment" (Camarinha-Matos \& Afsarmanesh, 2005).

Co-creation seizing phase: This is a business model design and strategic investment activity, done in a cooperative manner with multiple stakeholders.

It consists in the activities of analyzing and deciding when, where and how much to invest, and the development of the network of related companies, the design of the business model and the organizational design of the network.

Co-creation transformation phase: This is a recombination and reconfiguration of assets and the innovation network done in a cooperative manner with multiple stakeholders, within a context of effecting organizational change with co-development itself.

It is facilitated by decentralization and autonomy, cooperation, and the capacity for dialogue. A double-layered, live, self-reflective and flexible network system is recommended, that adapts according to contingencies, characterizing a co-evolution of the system.

Table 1 shows the transformation of value provided by the success of the stages of co-creation sensing, co-creation seizing and co-creation transformation, with the evolution of the potential value, for the defined and implemented value. It shows the details of the processes, which are complemented with aspects of innovation development, knowledge integration/ sharing, co-evolution, value co-creation, value capture, stakeholders' capabilities, and structural elements of an innovation network, enabling a multidimensional integrated sense.

Figure 1 shows an analysis among the stages of the integrated process, according to variables that characterize the innovation development, value creation and value capture. It shows the transformation from the intangible to the tangible, from the subjective to the objective, from the tacit to the explicit, from the conceptual to the concrete value. The reduction of uncertainty and subjectivity with the evolution of stages is related to the sharing of explicit knowledge and the anticipation and evaluation of stakeholders, reinforcing the commitment of stakeholders (Calabretta \& Gemser, 2015; Samset \& Volden, 2016; Takahashi \& Takahashi, 2019).

\section{Final remarks}

The present work allows an evolution in the practice of co-creation into a pluralist context, seeking to overcome the antagonisms and inherent necessities, synthesizing in an integrated approach the organizational processes that support co-creation with multiple stakeholders in an innovation network, as a way of how to reconfigure a network, since dynamic capabilities are integrating processes. There are two dimensions of integration. First, horizontal from the initial processes (co-creation sensing and co-creation seizing) to the co-creation transformation. Second, with the processes of creating and capturing value, developing innovation and integrating/sharing knowledge.

As theoretical contributions, the results of the work provides an integrated study of various types of dynamic capabilities, showing to be in line with the inquiries of research by Sunder et al. (2019) about the need for investigations of links or interrelationships between types of dynamic capabilities.

Regarding the contributions to managerial practice, the work provides a structure based on the sensing, seizing and transformation process integrated to the co-creation and value 


\begin{tabular}{|c|c|c|c|c|}
\hline & $\begin{array}{l}\text { Co-creation sensing } \\
\text { Recognition and creation } \\
\text { of opportunities }\end{array}$ & $\begin{array}{l}\text { Co-creation seizing } \\
\text { Business model design and } \\
\text { strategic investment } \\
\text { activity }\end{array}$ & $\begin{array}{l}\text { Co-creation transforming } \\
\text { Recombination and } \\
\text { reconfiguration of assets }\end{array}$ & $\begin{array}{r}\text { Integrated } \\
\text { co-creation } \\
\text { process }\end{array}$ \\
\hline \multirow[t]{2}{*}{$\begin{array}{l}\text { Evolution of the } \\
\text { performance of } \\
\text { multiple } \\
\text { stakeholders }\end{array}$} & \multirow{2}{*}{$\begin{array}{l}\text { It addresses an awareness } \\
\text { of the needs and } \\
\text { expectations of each } \\
\text { stakeholder, in a gradual } \\
\text { manner, in relation to the } \\
\text { needs and expectations of } \\
\text { other stakeholders, as } \\
\text { well as the potential role } \\
\text { of each stakeholder } \\
\text { (Ketonen-Oksi \& } \\
\text { Valkokar, 2019) }\end{array}$} & \multirow{2}{*}{$\begin{array}{l}\text { In this phase, stakeholders } \\
\text { use each other's capabilities } \\
\text { to share internal models, } \\
\text { perceptions, knowledge and } \\
\text { skills to create value. This } \\
\text { has the objective to propose } \\
\text { and define real values with } \\
\text { active communication } \\
\text { between the parties. } \\
\text { (Ketonen-Oksi \& Valkokar, } \\
\text { 2019) }\end{array}$} & \multirow{2}{*}{$\begin{array}{l}\text { There is the beginning and } \\
\text { development of new } \\
\text { relationships, and the } \\
\text { transfer and renewal of the } \\
\text { commitment assumed by } \\
\text { the companies in the } \\
\text { previous phase }\end{array}$} & 393 \\
\hline & & & & \\
\hline $\begin{array}{l}\text { Innovation } \\
\text { development }\end{array}$ & $\begin{array}{l}\text { Identification and creation } \\
\text { of the problem } \\
\text { The problem as an } \\
\text { opportunity to be solved } \\
\text { (Luchs et al., 2015; } \\
\text { Frishammar, Dahlskog, } \\
\text { Krumlinde, \& Yazgan, } \\
\text { 2016; Brown, 2009; Akbar } \\
\text { \& Mandurah, 2014) }\end{array}$ & $\begin{array}{l}\text { Creation of the problem's } \\
\text { solution } \\
\text { Emphasis on participatory } \\
\text { design (Luchs et al., 2015; } \\
\text { Frishammar et al., 2016; } \\
\text { Brown, 2009) }\end{array}$ & $\begin{array}{l}\text { Implementation of the } \\
\text { solution } \\
\text { A cooperative team or } \\
\text { networked team system is } \\
\text { composed for the } \\
\text { implementation of the } \\
\text { project, which normally } \\
\text { follows the design and } \\
\text { planning of the co-seizing } \\
\text { stage }\end{array}$ & \\
\hline \multirow[t]{2}{*}{$\begin{array}{l}\text { Characteristics and } \\
\text { process }\end{array}$} & $\begin{array}{l}\text { - Uncertainty (strongly } \\
\text { linked to lack of } \\
\text { information (Samset \& } \\
\text { Volden, 2016; Calabretta } \\
\text { \& Gemser, 2015)), } \\
\text { subjective and } \\
\text { ambiguous context } \\
\text { It is a fuzzy and dynamic } \\
\text { process (Akbar \& } \\
\text { Mandurah, 2014; Nonaka } \\
\text { \& Takeuchi, 1995) with } \\
\text { exploration insight, } \\
\text { creativity, critical } \\
\text { thinking, intense } \\
\text { discussions, and redoing }\end{array}$ & $\begin{array}{l}\text { - Generation of ideas } \\
\text { - Analysis and definition of } \\
\text { requirements, design of } \\
\text { experiences and } \\
\text { prototyping in the context } \\
\text { of an expanded network } \\
\text { of competences } \\
\text { - Interactive and creative } \\
\text { - Conflict and negotiation } \\
\text { management }\end{array}$ & $\begin{array}{l}\text { - Adjustments } \\
\text { - Change and co-evolution } \\
\text { - More structured and } \\
\text { scientific } \\
\text { - Reflection and } \\
\text { adaptation }\end{array}$ & \\
\hline & $\begin{array}{l}\text { - Interactive } \\
\text { - Use of sensemaking } \\
\text { (social process, fluid, } \\
\text { open and disorderly in } \\
\text { the collective sense), } \\
\text { with design of future } \\
\text { scenarios, and } \\
\text { observations } \\
\text { - Plausibility is sought, } \\
\text { not scientific } \\
\text { rationalism }\end{array}$ & & (continued) & $\begin{array}{r}\text { Table 1. } \\
\text { The integrated } \\
\text { co-creation process } \\
\text { with multiple } \\
\text { stakeholders based on } \\
\text { dynamic capabilities }\end{array}$ \\
\hline
\end{tabular}


INMR 19,4

394

\begin{tabular}{|c|c|c|c|}
\hline & $\begin{array}{l}\text { Co-creation sensing } \\
\text { Recognition and creation } \\
\text { of opportunities }\end{array}$ & $\begin{array}{l}\text { Co-creation seizing } \\
\text { Business model design and } \\
\text { strategic investment } \\
\text { activity }\end{array}$ & $\begin{array}{l}\text { Co-creation transforming } \\
\text { Recombination and } \\
\text { reconfiguration of assets }\end{array}$ \\
\hline $\begin{array}{l}\text { Organization and } \\
\text { network }\end{array}$ & $\begin{array}{l}\text { Formation of the initial } \\
\text { stakeholder group with } \\
\text { a central coordination } \\
\text { (Matinheikki, Artto, } \\
\text { Peltokorpi, \& Rajala, } \\
\text { 2016) } \\
\text { Start of a small network }\end{array}$ & $\begin{array}{l}\text { - Expansion of stakeholder } \\
\text { participation with the } \\
\text { active role of leaders with } \\
\text { network expansion } \\
\text { - Organizational design of } \\
\text { the network that will } \\
\text { implement the new } \\
\text { business model }\end{array}$ & $\begin{array}{l}\text { - Implementation of a } \\
\text { double-layered, live, self- } \\
\text { reflective and flexible } \\
\text { network system, with } \\
\text { deliberate community } \\
\text { - Orquestration } \\
\text { - Implementation of } \\
\text { project governance }\end{array}$ \\
\hline Value creation & Result: Value potential & Result: Value definition & $\begin{array}{l}\text { Result: Value } \\
\text { implementation }\end{array}$ \\
\hline Coordination & $\begin{array}{l}\text { - Front end coordination: } \\
\text { Flexible, facilitator, } \\
\text { instigator and initially } \\
\text { centralized } \\
\text { - Emphasis on } \\
\text { entrepreneurship } \\
\text { - Find and attract } \\
\text { interested parties } \\
\text { - Identification of } \\
\text { stakeholders' } \\
\text { competencies } \\
\text { - Information sharing }\end{array}$ & $\begin{array}{l}\text { - Front end coordination } \\
\text { - Emphasis on } \\
\text { entrepreneurship and } \\
\text { leadership } \\
\text { - Conflict and negotiation } \\
\text { management } \\
\text { - Participatory co-design }\end{array}$ & $\begin{array}{l}\text { - Detailed project planning } \\
\text { - Project implementation } \\
\text { management } \\
\text { - Emphasis on leadership } \\
\text { - Management of conflict, } \\
\text { risk and change } \\
\text { - Community of } \\
\text { deliberation }\end{array}$ \\
\hline Consultation & $\begin{array}{l}\text { - Sharing thoughts, ideas, } \\
\text { needs and expectations }\end{array}$ & - Compatibility of interests & - Effectiveness of interests \\
\hline Commitment & $\begin{array}{l}\text { - Consists of the } \\
\text { beginning of the } \\
\text { development of the } \\
\text { relationship and the } \\
\text { commitment and } \\
\text { compromise between all } \\
\text { involved }\end{array}$ & $\begin{array}{l}\text { - Strengthening } \\
\text { commitment } \\
\text { - Relationship development } \\
\text { and intensification }\end{array}$ & $\begin{array}{l}\text { - Relationship } \\
\text { management } \\
\text { - Renovation of } \\
\text { commitment } \\
\text { - Renewal of relationships } \\
\text { between stakeholders }\end{array}$ \\
\hline Value capture & Result: Value potenctial & Result: Value definition & $\begin{array}{l}\text { Result: Value } \\
\text { implementation }\end{array}$ \\
\hline Anticipation & $\begin{array}{l}\text { - Identification and } \\
\text { potential analysis of the } \\
\text { opportunity } \\
\text { - Initial identification of } \\
\text { roles in the network }\end{array}$ & $\begin{array}{l}\text { - Definition of the potential } \\
\text { value } \\
\text { - Clear definition of the } \\
\text { functions and roles of } \\
\text { each party in the network }\end{array}$ & $\begin{array}{l}\text { - Implementation of value } \\
\text { - Effectiveness of the role } \\
\text { in the network, authority } \\
\text { and leadership }\end{array}$ \\
\hline Evaluation & $\begin{array}{l}\text { - Based on perception of } \\
\text { potential additional } \\
\text { value. Intangibility }\end{array}$ & $\begin{array}{l}\text { - Tangible value (product, } \\
\text { market, financial and } \\
\text { risks), and intellectual } \\
\text { property }\end{array}$ & $\begin{array}{l}\text { From the stages of } \\
\text { project development, } \\
\text { risks, changes }\end{array}$ \\
\hline Transference & $\begin{array}{l}\text { - Share experiences, tacit } \\
\text { knowledge, insights } \\
\text { and perceptions } \\
\text { - Socialization }\end{array}$ & $\begin{array}{l}\text { - Complementarities and } \\
\text { sharing knowledge and } \\
\text { skills } \\
\text { - Promotion of integrated } \\
\text { thinking } \\
\text { - Externalization and } \\
\text { combination }\end{array}$ & $\begin{array}{l}\text { - Complementarity and } \\
\text { improvement of skills } \\
\text { and Knowledge } \\
\text { - Explicit knowledge } \\
\text { sharing } \\
\text { - Internalization } \\
\text { - Adaptation and } \\
\text { improvement of internal } \\
\text { processes }\end{array}$ \\
\hline
\end{tabular}




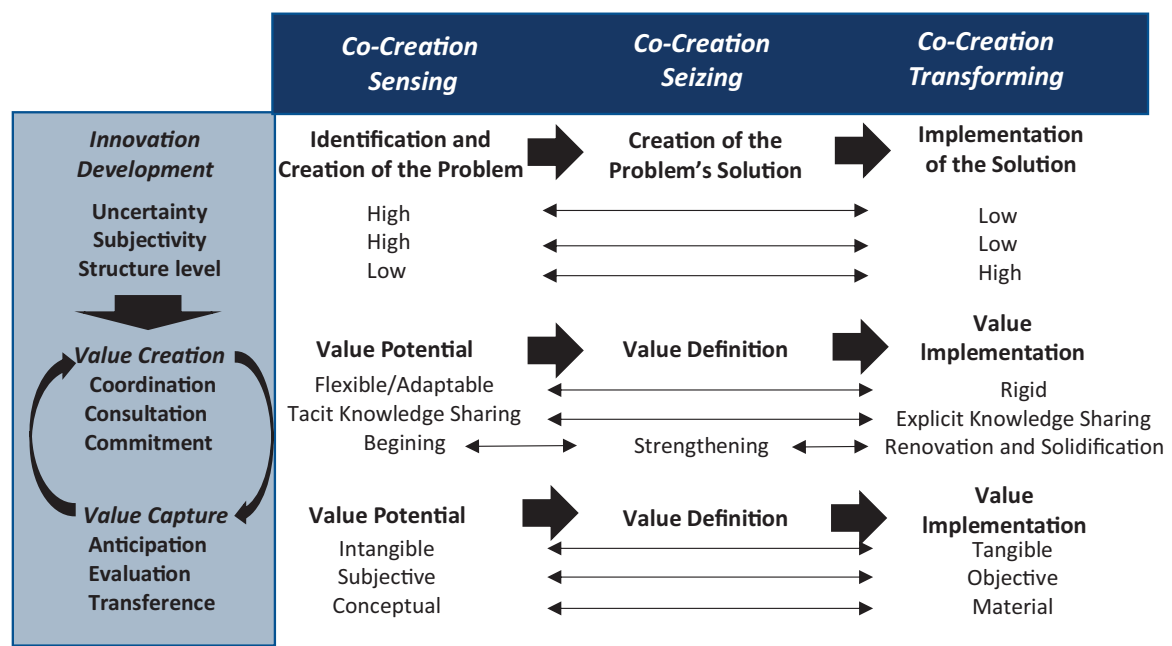

Integrated co-creation process

Source(s): Elaborated by the authors

capture, work networks and knowledge/integration sharing, that enables the elements for companies to work in a strategic process, in a cooperative and co-created manner.

Concerning the limitations of the work, there is the need to accomplish comparative case studies in different businesses and sectors, with different complexities and uncertainties likewise.

In future work, there should be studies of the purpose and values involved, the governance of the process, types of reconfiguration and structures of innovation network.

\section{References}

Aarikka_Stenroos, L., \& Ritala, P. (2017). Network management in the ra of ecosystems: Systematic review and management framework. Industrial Marketing Management, 67, 23-36.

Akbar, H., \& Mandurah, S. (2014). Project-conceptualisation in technological innovations: A knowledge-based perspective. International Journal of Project Management, 32(5), 759-772.

Argote, L., \& Miron-Spektor, E. (2011). Organizational learning: From experience to knowledge. Organization Science, 22(5), 1123-1137.

Arranz, N., \& de Arroyabe, J.C.F. (2012). Can innovation network projects result in efficient performance?. Technological Forecasting \& Social Change, 79(3), 485-497.

Batjargal, B. (2003). Social capital and entrepreneurial performance in Russia: A longitudinal study. Organization Studies, 24(3), 535-556.

Brown, T. (2009). Change by Design: How Design Thinking Transforms Organizations and Inspires Innovation. New York, NY: HarperCollins Publishers.

Burbiel, J. (2009). Creativity in research and development environments: A practical review. International Journal of Business Science and Applied Management, 4(2), 36-51.

Buur, J., \& Matthews, B. (2008). Participatory innovation. International Journal of Innovation Management, 12(3), 255-273.

Calabretta, G., \& Gemser, G. (2015). Integrating design into the fuzzy front end of the innovation process. In Luchs, M.G., Swan K.S., \& Griffin A. (Eds), Design Thinking: New Product Development Essentials From the PDMA. Hoboken, NJ: Wiley_Blackwell. 
INMR 19,4

Camarinha-Matos, L.M., \& Afsarmanesh, H. (2005). Collaborative networks: A new scientific discipline. Journal of Intelligent Manufacturing, 16, 439-452.

Camarinha-Matos, L.M., \& Afsarmanesh, H. (2007). A framework for virtual organization creation in a breeding environment. Annual Reviews in Control, 31, 119-135.

Capaldo, A. (2007). Network structure and innovation: The leveraging of a dual network as a distinctive relational capability. Strategic Management Journal, 28, 585-608.

Ceci, F., \& Iubatti, D. (2012). Personal relationships and innovation diffusion in SME networks: A content analysis approach, Research Policy, 41 (3), 565-579.

Collins, J.C., \& Porras, J.I. (1997). Feitas para durar, Rio de Janeiro: Campus.

Corsaro, D., Cantù, C., \& Tunisini, A. (2012). Actor's heterogeneity in innovation networks. Industrial Marketing Management, 41, 780-789.

De Kay, M. (2011). Integral Sustainable Design. New York, NY: Transformative perspectiveEarthscan.

Dell'Era, C., \& Landoni, P. (2014). Living lab: A methodology between user-centred design and participatory design. Creativity and Innovation Management, 23(2), 137-154.

Eisenhardt, D.T., \& Martin, J.A. (2000). Dynamic capabilities: What are they. Strategic Management Journal, 21(10/11), 1105-1121.

Frishammar, J., Dahlskog, E., Krumlinde, C., \& Yazgan, K. (2016). The front end of radical innovation: A case study of idea and concept development at prime group. Creativity and Innovation Management, 25(2), 179-198.

Galvano, M., \& Dalli, D. (2014). Theory of value co-creation: A systematic literature review. Managing Service Quality, 24(6), 643-683.

Gebauer, J., Füller, J., \& Pezzei, R. (2013). The dark and the bright side of co-creation: Triggers of member behavior in online innovation communities. Journal of Business Research, 66(9), 1516-1527.

Hakanen, T., \& Jaakkola, E. (2012). Co-creation customer-focused solutions within business networks: A service perspective. Journal of Service Management, 23(4), 593-611.

Hedlund, G. (1994). A model of knowledge management and the n-form corporation. Strategic Management Journal, 15, 73-90, doi: 10.1002/smj.4250151006.

Helfat, C.E., Finkelstein, S., Mitchell, W., Peteralf, W., Singh, H., Teece, D.J., \& Winter, S.G. (2007). Dynamic Capabilities: Understanding Strategic Change in Organization. Malden: WileyBlackwel.

Hsiao, R.L., Tsai, D.H., \& Lee, C.F. (2012). Collaborative knowing: The adaptive nature ofhed crossboundary Spanning. Journal of Management Studies, 49(3), 463-491.

Huizingh, E.K.R.E. (2011). Open innovation: State of the art and future perspectives. Technovation, 31(1), 2-9.

Ind, N., \& Coates, N. (2013). The meanings of co-creation. European Business Review, 25(1), 86-95.

Kazadi, K., Lievens, A., \& Mahr, D. (2016). Stakeholder co-creation during the innovation process: Identifying capabilities for knowledge creation among multiple stakeholders. Journal of Business Research, 69, 525-540.

Kelly, J., \& Matthews, B. (2014). Displacing use: Exploring alternative relationships in a humancentred design process. Design Studies, 35(4), 353-373.

Ketonen-Oksi, S., \& Valkokar, K. (2019). Innovation ecosystems as structures for value Co-creation. Technology Innovation Management Review, 9(2), 24-34.

Kodama, M. (2007). Project- Based Organization in the Knowledge-Based Society. Series on Technology Management $-v$. London: Imperial College Press, 12.

Kristensen, P.H., \& Lotz, M. (2011). Taking teams seriously in the co-creation of firms and economic agency. Organization Studies, 32(11), 1465-1484. 
Landoni, P., Dell'Era, C., Ferraloro, G., Peradotto, M., Karlsson, H., \& Verganti, R. (2016). Design contribution to the competitive performance of SMEs: The role of design innovation capabilities. Creativity and Innovation Management, 25(4), 484-499.

Lee, S.M., Olson, D.L., \& Trimi, S. (2012). Co-innovation: Convergenomics, collaboration, and cocreation for organizational values. Management Decision, 50(5), 817-831.

Luchs, M.G., Swan, K.S., \& Griffin, A. (2015). Design Thinking: New Product Development Essentials from the PDMA. New Jersey, NJ: Wiley_Blackwell.

Martin, R.L. (2007). The Opposable Mind: How Successful Leaders Win through Integrative Thinking. Boston: Harvard Business School Press.

Matinheikki, J., Artto, K., Peltokorpi, A., \& Rajala, R. (2016). Managing inter-organizational networks for value creation in the front-end of projects. International Journal of Project Management, 34, 1226-1241.

Michel, S., Vargo, S.L., \& Lusch, R.F. (2008). Reconfiguration of the conceptual landscape: A tribute to the service logic of richard normann. Journal of the Academy of Marketing Science, 36(1), $152-155$.

Miotti, L., \& Sachwald, F. (2003). Co-operative R\&D: Why and with whom? An integrated framework of analysis. Research Policy, 32(8), 1481-1499.

Müller, R., Zhai, L., Wang, A., \& Shao, J.A. (2016). Framework for governance of projects: Governmentality, governance structure and projectification. International Journal of Project Management, 34, 957-969.

Najera-Sanchez, J.J., Ortiz de Urbina, M., \& Mora-Valentin, E.M. (2020). Mapping value co-creation literature in the technology and innovation management field: A bibliographic coupling analysis. Frontiers in Psychology, 25 September 2020, doi: 10.3389/fpsyg.2020.588648.

Nonaka, I., \& Takeuchi, H. (1995). The Knowledge-Creating Company: How Japanese Companies Create the Dynamics of Innovation. Oxford: Oxford University Press.

Okhuysen, G.A., \& Eisenhardt, K.M. (2002). Integrating knowledge in groups: How formal interventions enable flexibility. Organizational Science, 13(4), 370-386.

Orlikowski, W.J. (2002). Knowing in practice: Enacting a collective capability in distributed Organizing. Organization Science, 13(3), 249-273.

Owen-Smith, J., \& Powell, W.W. (2004). Knowledge networks as channels and conduits: The effects of formal structure in the Boston biotechnology community. Organization Science, 15(1), 5-21.

Paré, G., Trudel, M.C., Jaana, M., \& Kitsiou, S. (2015). Synthesins information systems knowledge: A typology of literature reviews. Information \& Management, 52, 183-199.

Pera, R., Occhiocupo, N., \& Clarke, J. (2016). Motives and resources for value co-creation in a multistakeholder ecosystem: A managerial perspective. Journal of Business Research, 69, 4033-4041.

Perks, H., \& Moxey, S. (2011). Market-facing innovation networks: How lead firms partition tasks, share resources and develop capabilities. Industrial Marketing Management, 40, 1224-1237.

Pittaway, L., Robertson, M., Munir, K., Denyer, D., \& Neely, A. (2004). Networking and innovation: A systematic review of the evidence. International Journal of Management Reviews, 5/6(3\&4), 137-168.

Postma, C.E., Zwartkruis-Pelgrim, E., Daemen, E., \& Jia, D. (2012). Challenges of doing empathic design: Experiences from industry. International Journal of Design, 6(1), 59-70.

Prahalad, C.K., \& Ramaswamy, V. (2004). O futuro da competição. Rio de Janeiro: Elsevier.

Prahalad, C.K., \& Ramaswamy, V. (2004b). Co-creation experiences: The next pratice in value creation. Journal of Interactive Marketing, 18(3), 4-14.

Preikschas, M.W., Cabanelas, P., Rüdiger, K., \& Lampón, J.F. (2017). Value co-creation, dynamic capabilities and customer retention in industrial markets. Journal of Business and Industrial Marketing, 32(3), 409-420.
Integrated

co-creation

process 
INMR 19,4

Pullen, A.J.J., De Weerd-Nederhof, P.C., Groen, A.J., \& Fisscher, O.A. (2012). M. Open innovation in practice: Goal complementarity and closed NPD networks to explain differences in innovation performance for SMEs in the medical devices sector. Journal Production Innovation Management, 29(6), 917-934.

Ramaswamy, V. (2009). Leading the transformation to co-creation of value. Strategy \& Leadership Journal, 37(2), 32-37.

Ramaswamy, V., \& Ozcan, K. (2018). What is co-creation? An interactional creation framework and its implications for value creation. Journal of Business Research, 84, 196-205.

Ramirez, M.S., \& Penalvo, F.J.G. (2018). Co-creation and open innovation: Systematic literature review. Comunicar Media Education Journal, 26(54), doi: 10.3916/C54-2018-01.

Ranjan, K.R., \& Read, S. (2016). Value co-creation: Concept and measurement. Journal of the Academic Marketing. Science, 44, 290-315.

Reypens, C., Lievens, A., \& Blazevic, V. (2016). Leveraging value in multi-stakeholder innovation networks: A process framework for value co-creation and capture. Industrial Marketing Management, 56, 40-50.

Reypens, C., Lievens, A., \& Blazevic, V. (2020). Hybrid Orchestration in Multi-stakeholder Innovation Networks: Practices of mobilizing multiple, diverse stakeholders across organizational boundaries. Organization Studies, 42(1), 61-83.

Ribeiro, H.C.M., Tavares, V.C.M., \& Costa, B.K. (2016). Value co-creation: A bibliometric from 2000 to 2014. Revista Eletrônica de Estratégia and Negócios, 9(1), 118-151.

Rill, B. (2016). Resonant co-creation as an approach to strategic innovation. Journal of Organizational Change Management, 29(7), 1135-1152.

Romero, D., \& Molina, A. (2011) Collaborative networked organisations and customer communities: Value co-creation and co- innovation in the networking era. Production Planning and Control, 22 (5-6), 447-472.

Rowley, T., Behrens, D., \& Krackhardt, D. (2000). Redundant governance structures: An analysis of structural and relational embeddedness in the steel and semiconductor industries. Strategic Management Journal, 21, 369-386.

Roy, S., Sivakumar, K., \& Wilkinson, I.F. (2004). Innovation generation in supply chain relationships: A conceptual model and research propositions. Journal of the Academy of Marketing Science, 32(1), 61-79.

Samset, K., \& Volden, G.H. (2016). Front-end definition of projects: Ten paradoxes and some reflections regarding project management and project governance. International Journal of Project Management, 34(2), 297-313.

Sanders, E.B.N., \& Stappers, P.J. (2008). Co-creation and the new landscapes of design. CoDesign International Journal of Co Creation in Design and the Arts, 4(1), 5-18.

Scharmer, C.O. (2010). Teoria U. Como liderar pela percepção e realização do futuro emergente. São Paulo: Elsevier.

Stock, G.N., An Tsai, J.C., Jiang, J.J., \& Klein, G. (2021). Coping with uncertainty: Knowledge sharing in new product development projects. International Journal of Project Management, 39, 59-70.

Sunder, M. ., V., Ganesh, L.S., \& Marathe, R.R. (2019). Dynamic capabilities, a morphological analysis framework and agenda for future research. European Business Review, 31(1), 25-63.

Swan, J., \& Scarbrough, H. (2005). The politics of networked innovation. Human Relations, 58(7), 913-943.

Takahashi, S., \& Takahashi, V.P. (2007). Gestão de inovação de produtos: Estratégia, processo, organização e conhecimento. Rio de Janeiro: Campus Elsevier.

Takahashi, S. and Takahashi, V.P. (2019), Design method for front end in innovative project management, Proceedings of the XXX ISPM Innovation Conference: Celebrating Innovation 500 Years Since Da Vince, Firenze, Florence, Italy, pp. 1-12. 
Takeuchi, H., \& Nonaka, I. (2008). Gestão do conhecimento. Porto Alegre, RS: Bookman.

Teece, D.J. (2009). Dynamic Capabilities \& Strategic Management: Organizing for Innovation. Oxford: Oxford University Press.

Teece, D.J. (2016). Dynamic capabilities and entrepreneurial management in large organizations: Toward a theory of the (entrepreneurial) firm. European Economic Review, 86, 202-216.

Teece, D.J. (2018). Business models and dynamic capabilities. Long Range Planning, 51, 40-49.

Teece, D.J., Pisano, G., \& Shuen, A. (1997). Dynamic capabilities and strategic management. Strategic Management Journal, 18(7), 509-533.

Vargo, S., \& Lusch, R.F. (2008). Service-dominant logic: continuing the evolution. Journal of the Academy of Marketing Science, 36(1), 1-10.

Vargo, S.L., \& Lusch, R.F. (2016). Institutions and axioms: An extension and update of servicedominant logic. Journal of the Academy of Marketing Science, 44(5), 5-23.

Verona, G., \& Ravasi, D. (2003). Unbundling dynamic capabilities: An exploratory study of continuous product innovation. Industrial and Corporate Change, 12(3), 577-595.

Vicenzo, F.D., \& Mascia, D. (2012). Social capital in project-based organizations: Its role, structure, and impact on project performance. International Journal of Project Management, 30, 5-14.

Von Krogh, G.V., Ichijo, K., \& Nonaka, I. (2000). Enabling Knowledge Creation. Oxford: Oxford University Press.

Vrontis, D., Basile, G., Andreano, M.S., Mazzitelli, A., \& Papasolomou, I. (2020). The profile of innovation driven Italian SMEs and the relationship between the firms' networking abilities and dynamic capabilities. Journal of Business Research, 114, 313-324.

Weigel, L. (2015). Design thinking to brigde research and concept design. In Luchs, M.G., Swan K.S., \& Griffin A. (Eds), Design Thinking: New Product Development Essentials from the PDMA. New Jersey, NJ: Wiley_Blackwell, 59-69.

Zahra, S.A., Sapienza, H.J., \& Davidsson, P. (2006). Entrepreneurship and dynamic capabilities: A review, model and research agenda. Journal of Management Studies, 43(4), 917-955.

\section{Further reading}

Teece, D.J. (2007). Explicating dynamic capabilities: The nature and microfoundations of (sustainable) enterprise performance. Strategic Management Journal, 28(3), 1319-1350.

Willams, J. \& Aitken, R. (2011). The service-dominant logic of marketing and marketing ethics. Journal of Business Ethics, 102, 439-454.

\section{Corresponding author}

Sergio Takahashi can be contacted at: sergiota@usp.br

For instructions on how to order reprints of this article, please visit our website:

www.emeraldgrouppublishing.com/licensing/reprints.htm

Or contact us for further details: permissions@emeraldinsight.com 